\title{
OPTIMALISASI PEMENUHAN HAK KORBAN KEKERASAN TERHADAP PEREMPUAN MELALUI PUSAT PELAYANAN TERPADU
}

\author{
Penny Naluria Utami \\ Badan Penelitian dan Pengembangan Hukum dan HAM \\ Kementerian Hukum dan HAM RI \\ Jalan H.R. Rasuna Said Kavling 4-5 Kuningan - Jakarta Selatan 12940 \\ Email : penny_utami@yahoo.com
}

Tulisan Diterima: 18-03-2016 Direvisi: 22-04-2016 Disetujui: 15-07-2016

\begin{abstract}
Abstrak
Pemerintah Indonesia telah mengajukan kebijakan peraturan perlindungan perempuan dan anak sebagai prioritas nasional. Peraturan dimaksud untuk mengatasi kekerasan terhadap perempuan (KtP) di Indonesia. Berlakunya Undang-Undang Nomor 23 Tahun 2004 tentang Pemberantasan Kekerasan Dalam Rumah Tangga, Undang-Undang Nomor 21 Tahun 2007 tentang Pemberantasan Tindak Pidana Perdagangan Orang, serta Peraturan Menteri Negara Pemberdayaan Perempuan dan Perlindungan Anak RI Nomor 01 Tahun 2010 tentang Standar Pelayanan Minimal (SPM) Bidang Layanan Terpadu Bagi Perempuan dan Anak Korban Kekerasan. SPM merupakan instrumen penting untuk memastikan penghormatan dan pemenuhan hak-hak perempuan korban kekerasan. Standar tersebut adalah ukuran standar pelayanan minimum kepada perempuan korban kekerasan, terutama di bidang pengaduan dan laporan, kesehatan, bantuan dan penegakan hukum, rehabilitasi sosial, pemulangan dan reintegrasi sosial. Keputusan Menteri tersebut mengamanatkan pembentukkan Pusat Pelayanan Terpadu (PPT) di tingkat provinsi dan kabupaten serta unit ini terdiri dari pemerintah dan masyarakat sipil. Namun implementasi dari standar tersebut yang nampak dalam kinerja Pusat Pelayanan Terpadu belum optimal dan masih menemukan beberapa kesenjangan, antara lain: adanya variasi aturan daerah, pendanaan, koordinasi antar stakeholder yang terlibat, sarana prasarana, dan sumber daya manusia yang terlibat, sehingga terlihat bahwa pengejewantahan isi SPM masih menghadapi tantangan untuk perbaikan kedepannya.
\end{abstract}

Kata kunci: KtP, SPM dan PPT

\section{Abstract}

The Indonesian government has held regulatory policies protect women and children as a national priority. Regulations intended to address violence against women (VAW) in Indonesia. The enactment of Law No. 23 Year 2004 on Eradication of Domestic Violence, Law No. 21 of 2007 on the Eradication of Trafficking in Persons and Minister of State for women's Empowerment and Child Protection of Indonesia Number 01 Year 2010 on Minimum Service Standards (SPM) field of Integrated Services for women and children victims of violence. SPM is an important instrument to ensure respect for and fulfillment of the rights of women victims of violence. The standard is the standard size minimum services to women victims of violence, especially in the field of complaints and reports, health, relief and law enforcement, social rehabilitation, repatriation and social reintegration. The Ministerial Decree mandates the establishment of the Integrated Service Center at provincial and district levels, this unit consists of government and civil society. However implementation of these standards is apparent in the performance of the Integrated Service Center is not ideal and still find some gaps, among others: the variation of regional rules, funding, coordination among stakeholders involved, infrastructure, and human resources involved, so it looks that the manifestation SPM contents is still facing challenges for future improvements.

Keywords: violence against women (KtP), minimum service standards (SPM) and integrated service center (PPT). 


\section{PENDAHULUAN}

\section{Latar Belakang}

Kekerasan terhadap perempuan merupakan bentuk pelanggaran Hak Asasi Manusia yang dapat terjadi pada siapa saja, lintas status sosial, ekonomi dan pendidikan. Karena berawal dari ketidaksetaraan gender yang dialami, seringkali kekerasan terhadap perempuan dikenal sebagai kekerasan berbasis gender. Bukti empiris telah menunjukkan bahwa perempuan adalah kelompokyang banyak menjadikorban kekerasan dalam berbagai bentuk, antara lain seperti fisik, psikis, seksual, penelantaran, eksploitasi dan kekerasan lainnya.

Kekerasan adalah segala tindakan yang mengakibatkan kesakitan. Selama ini memang kesakitan belum pernah didefinisikan. Jika kesakitan merupakan kondisi kebalikan dari kesehatan, maka bisa mengambil definisi kesehatan dari Undang-Undang Nomor 36 tahun 2009 tentang kesehatan, yaitu: "Kesehatan adalah keadaan sehat, baik secara fisik, mental, spiritual maupun sosial yang memungkinkan setiap orang untuk hidup produktif secara sosial dan ekonomis." Sementara menurut Organisasi Kesehatan Dunia (WHO): "Kesehatan adalah keadaan sempurna, baik fisik, mental maupun sosial dan tidak hanya terbebas dari penyakit dan cacat."1

Rumah tangga idealnya adalah tempat yang aman untuk berlindung dari segala macam bentuk kejahatan terutama kekerasan yang bisa terjadi dimana saja dan kapan saja. Anggapan mengenai hal tersebut belum semuanya benar, karena sekarang ini banyak sekali terjadi tindakan kekerasan dalam rumah tangga (KDRT).

Pengesahan Undang-Undang tentang Penghapusan Kekerasan Dalam Rumah Tangga Nomor 23 Tahun 2004 merupakan terobosan hukum secara materiil, karena untuk pertama kalinya kekerasan dalam rumah tangga diatur sebagai kejahatan serius bukan isu privat. Selain itu undang-undang ini mengakomodir realitas bentuk-bentuk kekerasan dalam rumah tangga yang dialami korban tidak hanya fisik tetapi juga psikis, seksual dan penelantaran ekonomi.

1 Komnas Perempuan, Referensi bagi Hukum Pengadilan Agama tentang Kekerasan dalam Rumah Tangga (Jakarta: UNFPA, 2013),58.
Lahirnya undangundang ini diharapkan sebagai permulaan yang baik dalam upaya mengakhiri kekerasan dalam rumah tangga. ${ }^{2}$

Hak korban kekerasan telah diatur dalam Undang-Undang Nomor 23 Tahun 2004 tentang Penghapusan Kekerasan Dalam Rumah Tangga yaitu: a) Perlindungan dari pihak keluarga, kepolisian, kejaksaan, pengadilan, advokat, lembaga sosial, atau pihak lainnya baik sementara maupun berdasarkan penetapan perintah perlindungan dari pengadilan; b) Pelayanan kesehatan sesuai dengan kebutuhan medis; c) Penanganan secara khusus berkaitan dengan kerahisaan korban; d) Pendampingan oleh pekerja sosial dan bantuan hukum; dan e) Pelayanan bimbingan rohani.

Perlindungan dan pelayanan diberikan oleh institusi dan lembaga sesuai tugas dan fungsinya masing-masing, perlindungan yang diberikan berupa: a) Perlindungan oleh kepolisian berupa perlindungan sementara; b) Perlindungan oleh advokat diberikan dalam bentuk konsultasi hukum, melakukan mediasi dan negosiasi di antara pihak termasuk keluarga korban dan keluarga pelaku (mediasi), dan mendampingi korban di tingkat penyidikan, penuntutan, dan pemeriksaan dalam sidang pengadilan (litigasi), melakukan koordinasi dengan sesama penegak hukum, relawan pendamping, dan pekerja sosial (kerjasama dan kemitraan); c) Perlindungan dengan penetapan pengadilan dikeluarkan dalam bentuk perintah perlindungan yang diberikan selama 1 (satu) tahun dan dapat diperpanjang; d) Pelayanan tenaga kesehatan penting sekali artinya terutama dalam upaya pemberian sanksi terhadap pelaku kekerasan dalam rumah tangga; e) Pelayanan pekerja sosial diberikan dalam bentuk konseling untuk menguatkan dan memberi rasa aman bagi korban, memberikan informasi mengenai hak-hak korban; f) Pelayanan relawan pendamping diberikan kepada korban mengenai hak-hak korban untuk mendapatkan seorang atau beberapa relawan pendamping, mendampingi korban; dan g) Pelayanan oleh pembimbing rohani diberikan untuk memberikan penjelasan mengenai hak, kewajiban dan memberikan penguatan iman dan takwa kepada korban.

2 Sulistyowati Irianto, Perempuan \& Hukum: Menuju Hukum yang Berperspektif Kesetaraan dan Keadilan (Jakarta: Yayasan Obor Indonesia, 2006). 
Jumlah kasus Kekerasan terhadap Perempuan (KtP) pada tahun 2014 berdasarkan Catatan Tahunan (CATAHU) Komnas Perempuan sebesar 293.220 kasus. Sebagian besar dari data tersebut diperoleh dari data kasus atau perkara yang ditangani oleh Pengadilan Agama (PA), yaitu mencapai 280.710 kasus atau berkisar $96 \%$. Sisanya sejumlah 12.510 kasus atau berkisar 4\% bersumber dari 191 lembaga-lembaga mitra pengada layanan. Dari sumber data tersebut ditemukan bahwa penyebab perceraian dari kasus yang ditangani oleh PA sebagai berikut: kekerasan psikis yang mencapai persentase $47 \%$ mencakup: poligami tidak sehat, krisis akhlak, cemburu, kawin paksa, kawin di bawah umur, kekejaman mental, dihukum, politis, gangguan pihak ketiga, tidak ada keharmonisan; kekerasan ekonomi (46\%) mencakup masalah ekonomi dan tidak tanggung jawab; kekerasan fisik $(3 \%)$ mencakup kekejaman jasmani dan cacat biologis. Bentuk KDRT mencakup: kekerasan terhadap isteri (KTI, 59\%), kekerasan dalam pacaran (KDP, 21\%), kekerasan terhadap anak perempuan (KTAP, 10\%), kekerasan dari mantan suami (KMS, 6\% kasus), kekerasan terhadap pekerja rumah tangga (PRT, 4\%) dan kekerasan mantan pacar (KMP, 1\%). ${ }^{3}$

Gambar 1

\section{Jumlah KTP dari Tahun 2004-2014 CATAHU 2015}

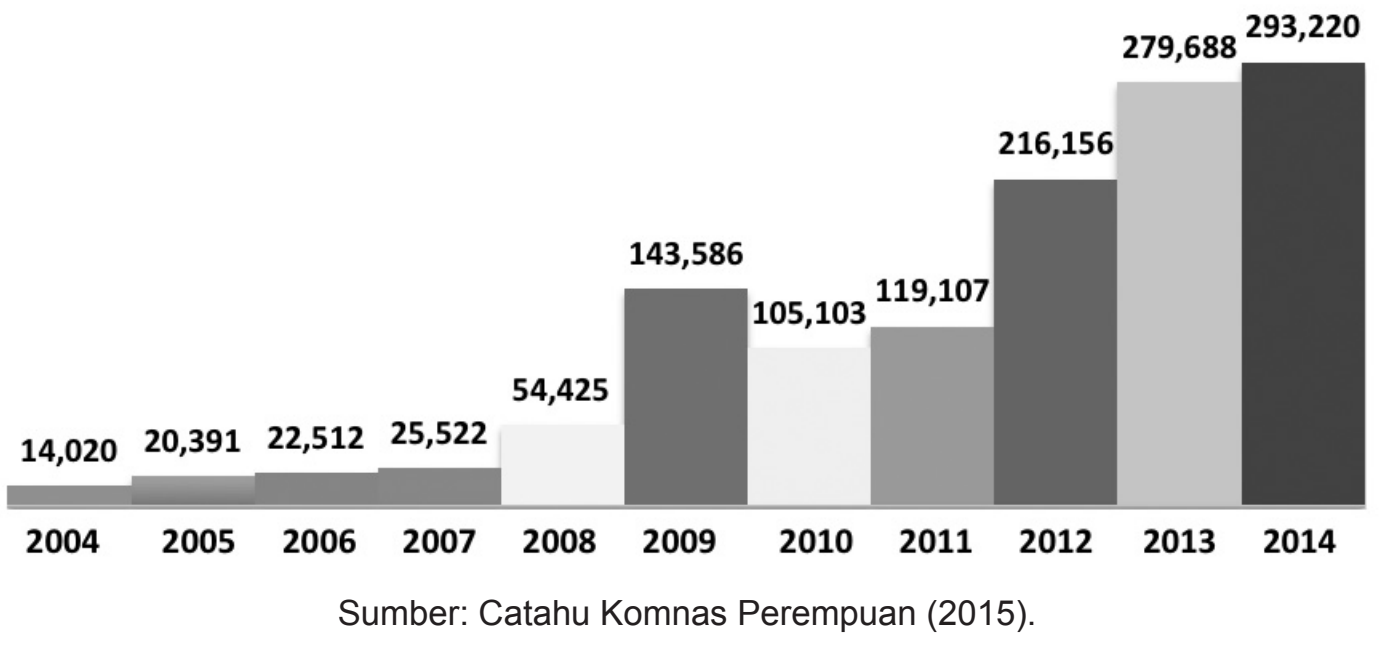

Angka-angka ini merupakan fenomena gunung es, karena masih banyak perempuan korban tidak berani (malu) bahkan beranggapan tabu untuk menceritakan pengalaman kekerasannya dan terkadang lambat mendatangi lembaga pengada layanan untuk meminta pertolongan. Keengganan dan ketidakmampuan ini lebih banyak disebabkan oleh stigma yang berkembang di masyarakat bahwa perempuan korban kekerasan justru dianggap sebagai pihak yang bersalah, 'perempuan penggoda' atau tidak mempunyai akhlak yang baik dan oleh karenanya sudah sepantasnya mendapat tindakan kekerasan seperti yang dilaminya.
Pembentukan Pusat Pelayanan Terpadu Pemberdayaan Perempuan Perempuan dan Anak (P2TP2A) merupakan urusan wajib Pemerintah Daerah. Hal ini sesuai dengan amanat Undang-Undang Nomor 35 Tahun 2014 tentang Perubahan Atas Undang-Undang Nomor 23 Tahun 2002 tentang Perlindungan Anak, Undang-Undang Nomor 23 Tahun 2004 tentang Penghapusan Kekerasan dalam Rumah Tangga, Undang-Undang Nomor 13 Tahun 2006 tentang Perlindungan Saksi Korban dan Undang-Undang Nomor 21 Tahun 2007 tentang Pemberantasan Tindak Pidana Perdagangan Orang dan Peraturan Menteri Negara Pemberdayaan Perempuan dan Perlindungan Anak RI Nomor 01

3 Komnas Perempuan, Catatan Tahunan Komnas Perempuan Tahun 2015 (Jakarta: Komnas Perempuan, 2015). 
Tahun 2010 tentang Standar Pelayanan Minimal (SPM) Bidang Layanan Terpadu bagi perempuan dan anak korban kekerasan.

Berdasarkan Pasal 1 dalam Permen tersebut, SPM ini merupakan alat untuk mengukur kinerja Unit Pelayanan Terpadu dalam pemenuhan hak bagi perempuan dan anak korban kekerasan meliputi 5 (lima) jenis layanan, yakni: layanan pengaduan, layanan kesehatan, rehabilitasi sosial, penegakan dan bantuan hukum, serta pemulangan dan reintegrasi sosial. Saat ini, layanan bagi perempuan korban juga sangat terbatas, unit penanganan pengaduan di kepolisian belum menjadi prioritas dan pusat layanan terpadu yang dikoordinir oleh Kementerian Pemberdayaan Perempuan dan Perlindungan Anak kerap terhambat oleh struktur dan dukungan seadanya. ${ }^{4}$

Komnas Perempuan mencatat kurang lebih $50 \%$ penanganan kasus kekerasan terhadap perempuan melibatkan lembagalembaga yang diwajibkan dalam SPM tersebut. Hal ini menunjukkan bahwa keterlibatan penanggungjawab secara multi sektoral telah memberikan respon yang signifikan, meski belum secara maksimal. ${ }^{5}$ Kondisi ini belum tercapai secara merata di seluruh Indonesia karena tidak semua Pemerintah Daerah merespons kebutuhan korban sesuai hak-haknya yang diatur dalam indikator layanan SPM tersebut melalui Pusat Pelayanan Terpadu.

Berdasarkan SPM, Pusat Pelayanan Terpadu harus dibentuk oleh setiap pemerintah daerah baik yang berada di Provinsi, Kabupaten/ Kota, karena saat ini baru ada sekitar 250 Pusat Pelayanan Terpadu padahal pemerintah daerah di seluruh Indonesia berjumlah 534 . Dalam penanganan kasus, lembaga pengada layanan yang dikelola oleh masyarakat mengembangkan sistem rujukan dan kerjasama secara kelembagaan yang dituangkan dalam nota kesepahaman. Dengan nota kesepahaman ini proses penanganan kasus diharapkan dapat dilakukan dengan lebih cepat.

4

Peraturan Menteri Negara Pemberdayaan Perempuan dan Perlindungan Anak Republik Indonesia Nomor 01 Tahun 2010 tentang Standar Pelayanan Minimal (SPM) Bidang Layanan Terpadu Bagi Perempuan dan Anak Korban Kekerasan.

5 Komnas Perempuan, Catatan Tahunan Komnas Perempuan Tahun 2015 (Jakarta: Komnas Perempuan, 2015).

\section{Rumusan Masalah}

Permasalahannya, bagaimanakaheksistensi pusat pelayanan terpadu dalam memenuhi hak perempuan korban kekerasan sebagaimana diamanatkan peraturan perundang-undangan dan bagaimana jaringan kerjasama lintas sektor dalam pemenuhan hak perempuan korban kekerasan.

\section{Tujuan}

Tujuan penulisan ini adalah untuk mendeskripsikan atau menggambarkan data yang diperoleh dari penelitian dan dianalisis terhadap peran pusat pelayanan terpadu dalam memenuhi hak korban kekerasan terhadap perempuan untuk mendapatkan pelayanan sesuai amanat peraturan perundang-undangan dan menggambarkan jaringan kerjasama lintas sektor pemenuhan hak korban kekerasan terhadap perempuan.

\section{Metodologi Penelitian}

Penelitian ini hanya fokus pada pemenuhan hak korban kekerasan terhadap perempuan di Pusat Pelayanan Terpadu yang ada di provinsi secara purposif sampling yang berarti teknik pengambilan sampel secara sengaja. Jadi, sampel diambil tidak secara acak tetapiditentukan sendiri oleh peneliti yang secara umum terjadi Manado (Sulawesi Utara), Medan (Sumatera Utara), Jayapura (Papua) dan DKI Jakarta, dimana munculnya perceraian dilatarbelakangi banyak faktor, diantaranya kemiskinan yang mengakibatkan stres, lalu mereka terjerumus minum-minuman keras yang memicu kekerasan dalam rumah tangga (KDRT).

Penelitian ini merupakan penelitian kualitatif yang menekankan pada aspek pemahaman secara mendalam terhadap suatu masalah daripada melihat permasalahan untuk digeneralisasi. Dengan pendekatan deskriptif analisis yang ingin mendeskripsikan atau menggambarkan data yang telah terkumpul sebagaimana adanya tanpa bermaksud membuat kesimpulan yang berlaku untuk umum atau generalisasi tetapi hanya menjelaskan kelompok data itu saja. Untuk mendapatkan validitas data yang diharapkan, maka menggunakan metode Triangulasi, yakni metode kombinasi pengumpulan data dengan cara dan sumber yang berbeda untuk studi tentang fenomena yang sama. Pengumpulan 
data primer berasal dari informan kunci yang diklasifikasikan sebagai berikut: Pemerintah Daerah, Dinas Sosial, Pusat Pelayanan Terpadu (PPT), Kepolisian, Badan Pemberdayaan Perempuan dan organisasi kemasyarakatan yang responsif gender, sementara data sekunder dalam penelitian ini berupa statistik deskriptif yang menggambarkan besaran masalah penanganan pengaduan kekerasan terhadap perempuan serta data yuridis normatif berupa telaahan norma hukum, peraturan dan kebijakankebijakan yang dikeluarkan oleh pemerintah pusat dan daerah dalam rangka pemenuhan hak korban kekerasan terhadap perempuan di 4 (empat) lokasi penelitian.

Gambar dibawah memperlihatkan kondisi yang selama ini terjadi tatkala setiap disiplin atau bidang keahlian bekerja sendiri-sendiri dan hanya mengikuti SOP (Standard Operating Procedures) serta langgam kerja masing-masing didalam memberikan layanan dengan kondisi seperti itu, perempuan korban kekerasan akan terhimpit oleh 'beban' masing-masig disiplin atau bidang keahlian tersebut.

\section{Gambar 3}

\section{Kerangka Pemikiran}

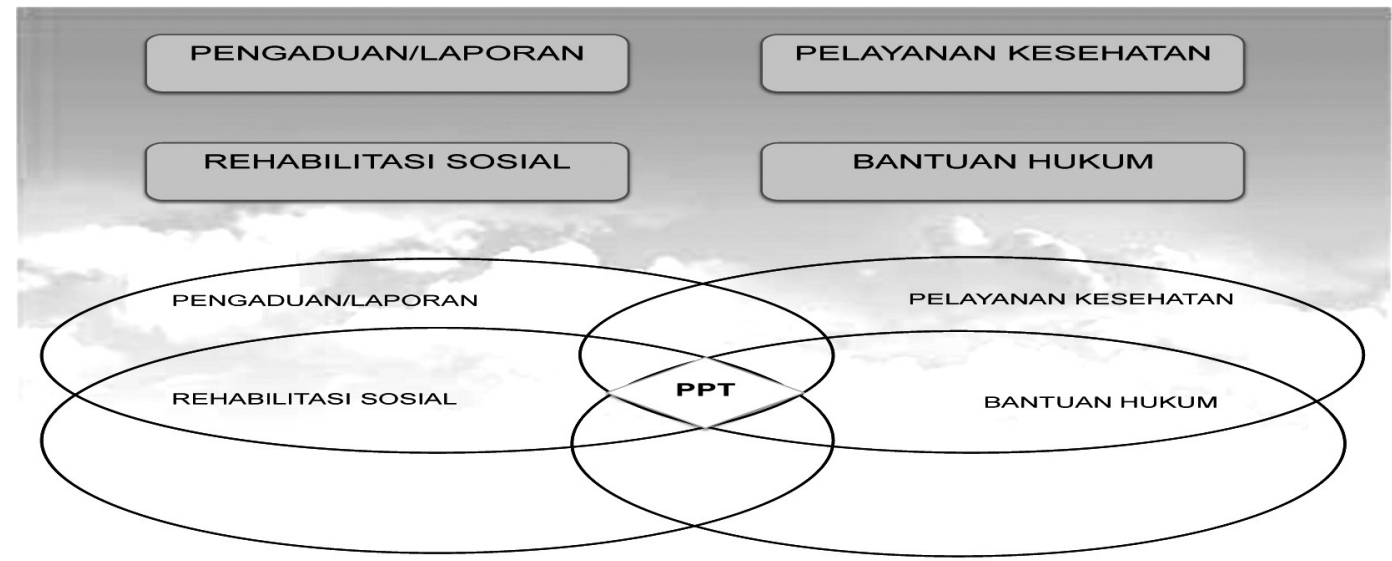

Pada gambar diatas, irisan pertautan keempat lingkaran adalah ruang atau arena yang harus dibangun bersama oleh lembagalembaga pengada layanan. Keterpaduan bukan berarti begitu saja menyatukan institusi pengada layanan, akan tetapi mengintegrasikan pertautan disiplin pelayanan di dalam layanan sehingga layanan tersebut mampu memberdayakan perempuan korban tindak kekerasan.

Contoh yang paling sering dialami oleh korban adalah korban diminta mengulang-ulang detail tindak kekerasan yang dialaminya berkalikali. Apalagi pada prakteknya, korban mau tak mau harus menempuh prosedur yang panjang dan berbelit-belit atau kesana kemari, tanpa mempertimbangkan apakah korban telah cukup siap untuk itu.

\section{PEMBAHASAN}

\section{Eksistensi Pusat Pelayanan Terpadu Dalam Memenuhi Hak Perempuan Korban Kekerasan}

Pada tingkat kebijakan, masalah perempuan dan anak korban kekerasan di Indonesia sejak tahun 1997 telah mendapatkan perhatian yang cukup. Hal ini terbukti dengan pengesahan 7 (tujuh) undang-undang yang terkait dengan penanganan masalah kekerasan terhadap perempuan dan anak yang meliputi: (a) UndangUndang Nomor 3 Tahun 1997 tentang Pengadilan Anak yang telah direvisi menjadi Undang-Undang Nomor 11 Tahun 2012 tentang Sistem Peradilan Pidana Anak; (b) Undang-Undang Nomor 23 Tahun 2002 tentang Perlindungan Anak mengalami perubahan menjadi Undang-Undang Nomor 35 Tahun 2014 tentang Perubahan atas Undang-Undang Nomor 23 Tahun 2002 tentang Perlindungan Anak; (c) Undang-Undang Nomor 
23 Tahun 2004 tentang Penghapusan Kekerasan Dalam Rumah Tangga; (d) Undang-Undang Nomor 13 Tahun 2006 tentang Perlindungan Saksi dan Korban; (e) Undang-Undang Nomor 21 Tahun 2007 tentang Pemberantasan Tindak Pidana Perdagangan Orang; dan (f) UndangUndang Nomor 36 Tahun 2009 tentang Kesehatan.

Selanjutnya, Pemerintah Indonesia mengeluarkan Peraturan Pemerintah Nomor 4 Tahun 2006 tentang Penyelenggaraan dan Kerjasama Pemulihan Korban Kekerasan Dalam Rumah Tangga yang merupakan amanat Pasal 43 Undang-Undang Nomor 23 Tahun 2004. Peraturan Pemerintah ini mengatur kerjasama penyelenggaraan pemulihan korban kekerasan dalam rumah tangga yang harus dilaksanakan oleh instansi pemerintah, pemerintah daerah dan lembaga sosial sesuai dengan tugas dan fungsi masing-masing termasuk penyediaan fasilitas yang diperlukan untuk pemulihan korban. Pada Pasal 3 Peraturan Pemerintah ini mengamanatkan perlunya dibuat pedoman pemulihan korban kekerasan dalam rumah tangga yang sensitif gender yang dirumuskan dalam standar pelayanan minimal.

Dalam Peraturan Pemerintah tersebut dinyatakan bahwa pemerintah kabupaten atau kota membentuk dan menyelenggarakan Pusat Pelayanan Terpadu (PPT) yang diatur dalam peraturan daerah kabupaten atau kota. Selain itu, untuk menjamin eksistensi dari PPT tersebut diperlukan dukungan sarana dan prasarana serta anggaran operasionalnya. Dalam Peraturan Pemerintah tersebut juga diamanatkan untuk membentuk PPT di daerah perbatasan, yang merupakan daerah transit, debarkasi untuk mempermudah dan mempercepat penanganan saksi dan atau korban tindak pidana perdagangan orang.

Untukmenjamin kualitas pelayanan terhadap saksi dan atau korban tindak pidana perdagangan orang, pada Pasal 7 Peraturan Pemerintah Nomor 9 Tahun 2008 mengamanatkan Menteri Negara Pemberdayaan Perempuan untuk menyusun suatu standar pelayanan minimal dan prosedur standar operasional yang akan menjadi pedoman dalam penyelenggaraan pelayanan terpadu oleh kementerian dan lembaga terkait dan PPT di daerah. Menindaklanjuti korban kekerasan yang terus meningkat maka pada 2010 Kementerian
Pemberdayaan Perempuan dan Perlindungan Anak kemudian mengeluarkan Peraturan Menteri Nomor 01 Tahun 2010 tentang Standar Pelayanan Minimal Bidang Layanan Terpadu bagi Perempuan dan Anak Korban Kekerasan yang menjadi panduan daerah untuk membentuk Unit Pelayanan Terpadu dari berbagai sektor, termasuk diantaranya Pusat Pelayanan Terpadu Pemberdayaan Perempuan dan Anak (P2TP2A) yang harus dibentuk oleh pemerintah daerah di tingkat provinsi, kabupaten dan kota.

Temuan penelitian ini, menunjukkan bahwa seluruh daerah penelitian telah memiliki P2TP2A yang berfungsi sebagai pusat pelayanan terpadu bagi perempuan dan anak korban kekerasan, meski dalam perkembangannya tidak semua berjalan secara maksimal dalam memenuhi hak korban karena kendala dukungan kebijakan dan anggaran dari pemerintah daerah, namun juga masalah koordinasi dengan aparat penegak hukum dan instansi terkait lainnya. Jadi, layanan bagi perempuan korban kekerasan, sesuai dengan apa yang dibutuhkan, biasanya meliputi layanan konseling, pendampingan atau curhat, pendampingan hukum apabila korban ingin memproses perkaranya secara litigasi, ataupun layanan medik yang biasanya mencakup juga layanan medik darurat. Layanan tersebut masing-masing dikelola oleh pihak yang berbeda, diantaranya adalah organisasi perempuan (misalnya women's crisis centre), lembaga non-pemerintah (misalnya lembaga bantuan hukum) maupun pemerintah seperti badan pemberdayaan perempuan (misalnya P2TP2A), kepolisian (misalnya RPK) dan rumah sakit (misal PPT).

Pelayanan diadakan mengikuti ketersediaan keahlian, sumberdaya manusia dan fasilitas yang ada. Jika tidak merasa sanggup melayani karena keterbatasan tenaga, fasilitas ataupun dana, biasanya mencari kenalan lain dan merujuknya kesana. Proses rujukan dilakukan atas dasar kepercayaan atau hubungan baik beberapa orang di antara lembaga-lembaga tersebut. Sehubungan dengan keterbatasan tersebut, acapkali lembaga layanan tidak dapat memenuhi kebutuhan korban secara memadai sebagaimana yang dibutuhkan. Apalagi bila korban tempat tinggalnya terlampau jauh untuk dapat mengakses lokasi layanan. 
Aparat penegak hukum sebagai pemegang otoritas publik dalam sebuah negara memiliki kewajiban untuk membuat hukum tentang penegakan hukum yang baik, melaksanakan penegakan hukum dengan baik, menciptakan keamanan dan ketertiban umum bagi setiap orang yang ada di wilayah ini. Namun kewajiban tersebut harus dilakukan dengan penghormatan, pemenuhan dan perlindungan HAM, utamanya hak-hak perempuan. Ruang pelayanan yang ada selama ini di kepolisian sebatas untuk pengaduan tindak pidana yang diatur dalam Undang-Undang Penghapusan Kekerasan Dalam Rumah Tangga. Dengan adanya ruang pelayanan khusus, saksi dan korban dapat memberikan keterangan dalam keadaan nyaman, tenang, utuh dan tidak dipermalukan dihadapan orang lain. Umumnya peningkatan jumlah unit layanan bagi perempuan dan anak belum diikuti dengan meningkatnya kualitas pelayanan. Staf penyedia layanan pada unit-unit tersebut "tidak sensitif gender", dan belum diberikan pelatihan peningkatan kapasitas yang memadai. Banyak lembaga layanan tersebut belum memiliki fasilitas yang cukup dan representatif, khususnya tempat penampungan bagi korban. Unit layanan yang sudah ada terkadang kurang diikuti dengan kampanye yang gencar. Kelembagaan memang perlu diperkuat, namun pada saat yang sama, pendidikan serta sosialisasi atau kampanye untuk memerangi kekerasan terhadap perempuan juga harus dilakukan.

Penyelenggaraan pelayanan perempuan korban kekerasan di Papua diimplementasikan dalam berbagai regulasi yang dikeluarkan baik oleh Gubernur maupun instansi-instansi terkait didalam pemerintah daerah Papua. Melalui Biro Pemberdayaan Perempuan dan Perlindungan Anak Provinsi Papua yang mempunyai tugas pokok fungsi merumuskan bahan pembinaan penyelenggaraan pemberdayaan perempuan dalam mewujudkan keadilan dan kesetaraan gender, berupaya melaksanakan salah satu tugas pemulihan hak perempuan Papua Korban Kekerasan dan Pelanggaran Hak Asasi Manusia seperti diamanatkan Peraturan Daerah Khusus (Perdasus) Nomor 1 Tahun 2011. Upaya ini adalah untuk memberikan perlindungan, pemajuan, penegakan hukum dan pemenuhan hak asasi manusia melalui penciptaan suasana yang aman, tenteram damai dan sejahtera.
Setiap orang bebas dari kekerasan termasuk didalamnya perempuan.

Pemenuhan hak perempuan korban Kekerasan di Papua juga dilakukan oleh Unit Pelayanan Perempuan dan Anak (PPA) Polda Papua. UPPAPolda Papua dalam tugas fungsinya melaksanakan pelayanan perlindungan dan penegakan dan bantuan hukum. Dengan fasilitas yang cukup memadai, termasuk 70 Polwan yang menangani perempuan dan anak korban Kekerasan. Pelayanan Polda Papua cukup optimal dalam proses pemeriksaan, penyidikan sampai dengan penegakan hukum maupun perlindungan dari berbagai ancaman. Upaya cukup keras ini tidak diimbangi kesadaran masyarakatkorban Kekerasan untukmeneruskan kasus yang dialaminya pada proses hukum, sehingga hal ini menjadi kasus yang senantiasa berulang. Disinilah sebenarnya peran Biro Pemberdayaan Perempuan maupun instansi lain seperti Dinas Sosial untuk melakukan upaya promotif dan pencegahan melalui program dan kegiatan yang dijalankan sehingga kekerasan bukan merupakan proses senantiasa berulang.

Beberapa hal yang juga menjadi permasalahan adalah rumah aman yang sampai saat ini belum difungsikan secara maksimal. Rumah aman berada di lingkungan Polda Papua dengan bangunan yang dibiayai Pemda, semestinya segera ditindaklanjuti dengan Nota Kesepahaman agar rumah aman dapat berjalan sesuai yang diharapkan. Rumah aman akan sangat strategis karena berada ditempat yang benar-benar aman sehingga sesuai fungsinya.

P2TPA Provinsi Papua tidak berjalan sesuai harapan karena terkendala kepengurusannya yang baru belum terbentuk sehingga kegiatan operasionalnya dikembalikan ke Biro Pemberdayaan Perempuan dan Perlindungan Anak Provinsi Papua. P2TPA Provinsi Papua seharusnya menjadi pusat koordinasi baik penanganan di provinsi maupun menjadi koordinator di wilayah kabupaten dan kota di wilayah Papua. Kekerasan terhadap perempuan dan anak di kota Jayapura cukup tinggi terbukti banyaknya pengaduan yang masuk dan penanganan yang melibatkan banyak sektor termasuk lembaga adat. Bentuk-bentuk diskriminasi dan tindak Kekerasan terhadap perempuan masih memprihatinkan yang terjadi disana. 
Pemenuhan Hak perempuan korban Kekerasan di Sulawesi Utara ditangani langsung oleh Badan Pemberdayaan Perempuan dan Perlindungan Anak. Penanganan korban ditangani dengan beberapa mitra kerja, seperti Rumah Sakit Umum Malalayang dan Rumah Sakit Bhayangkara Manado dalam hal penanganan medis, Polda Sulut dan PolresPolres di jajaran Polda Sulut dalam penanganan bidang hukum dan Posbakumadin (Pos Bantuan Hukum Advokat Indonesia) yang merupakan salah satu dari Peradi Sulawesi Utara untuk membantu permasalahan hukum bagi korban kekerasan. Fungsi P2TP2A Sulawesi Utara melekat pada BP3A sehingga semua anggaran berada di BP3A. Pembagian peran tidak jelas meskipun dari sisi regulasi Pemerintah Sulawesi Utara mempunyai semangat yang tinggi terkait permasalahan perempuan dan anak. P2TP2A bukan lembaga otonom, hal ini membuat P2TP2A tidak bisa melakukan pelayanan secara maksimal, meskipun P2TP2A memberikan layanan pengaduan, pendampingan dan memberikan rujukan baik medis maupun hukum serta memberikan layanan rumah aman. Selain kendala anggaran dalam melaksanakan penanganan korban Kekerasan P2TP2A juga tidak memadai dalam sarana prasarana serta shelter yang tidak aman dan nyaman. Sumber daya manusia di P2TP2A juga sangat terbatas sehingga kinerja juga tidak maksimal. Pelayanan yang tidak maksimal juga disebabkan tugas fungsi yang melekat pada setiap pejabat dan anggota yang duduk dalam kelembagaan, sehingga program kegiatan menjadi tumpang tindih dengan tugas dan fungsi institusi dan kelembagaan, meskipun alur pelayanan sangat jelas dibuat.

Biro Pemberdayaan Perempuan, Anak dan KeluargaBerencana(BPPAKB)ProvinsiSumatera Utara menjadi ujung tombak penanganan kekerasan terhadap perempuan. Melalui Pusat Pelayanan Terpadu Pemberdayaan Perempuan dan Anak (P2TP2A) Provinsi Sumatera Utara yang dibawah koordinasi BPPAKB melaksanakan pelayanan perempuan korban kekerasan dalam pemenuhan hak mereka. Pelayanan yang diberikan sesuai dengan standar pelayanan minimal dan mempunyai rumah aman yang terpisah dan aman dari jangkauan masyarakat. Pelayanan di P2TP2A cukup memadai dengan pelayanan kesehatan, psikososial maupun pendampingan hukum. Upaya pemberdayaan juga dilakukan oleh P2TP2A dengan berbagai pelatihan yang dilakukan.

Polda Sumatera Utara dalam penanganan korban kekerasan ditangani Sub Direktorat IV Remaja, Anak dan Wanita (Subdit Renakta) yang didalamnya termasuk UPPA. Pelayanan dilakukan di Ruang Pelayanan Khusus (RPK) dengan suasana yang nyaman. Untuk kebutuhan shelter Polda bekerjasama dengan P2TP2A atau Lembaga Swadaya Masyarakat yang lain yang representatif. Koordinasi dengan lembaga layanan lain berjalan cukup baik, termasukrujukan atau pelayanan di Rumah Sakit di Sumatera Utara. Rumah Sakit yang menjadi rujukan ada beberapa yaitu, RS dr. Pirngadi Medan, RS H. Adam Malik dan RS Bhayangkara Kepolisian Daerah Sumatera Utara, selalin itu beberapa Puskesmas yang sipa melayani perempuan dan anak korban Kekerasan dengan gratis.

Pemenuhan hak korban akan kesehatan menjadi prioritas pemerintah provinsi Sumatera Utara, termasuk Visum et Repertum (VeR), perawatan dan kebutuhan medis dan psikis korban.Semuapenanganan dilaksanakan melalui alur yang sudah ditentukan. Karena koordinasi yang baik semua korban selalu diarahkan untuk menyelesaikan kasusnya dengan sebaik-baiknya samapai pada penegakan hukum. Dengan angka Kekerasan terhadap perempuan yang meningkat dari tahun ke tahun mengindikasikan bahwa perlu adanya upaya preventif yang lebih efektif sehingga bisa menekan hal tersebut.

$$
\text { Badan Pemberdayaan Masyarakat }
$$
Perempuan dan Keluarga Berencana (BPMPKB) Provinsi DKI Jakarta menjadi ujung tombak dalam memenuhi hak perempuan dan anak korban Kekerasan. Tanggungjawab besar BPMPKB adalah mengupayakan pelayanan perempuan dan anak dapat terlayani dengan dengan baik yang secara teknis pelayanan berada pada Pusat Pelayanan Terpadu Pemberdayaan Perempuan dan Anak (P2TP2A) Provinsi DKI Jakarta.

Seperti P2TP2A Jakarta, dari empat gubernur tidak ada yang berubah. Setiap tahun selalu diisukan mau ditutup, sehingga sejak dulu P2TP2A Jakarta selalu berjuang di sistem, bukan pada masalah punya siapa. Di daerah ada yang pengurusnya sampai 100 orang dan bahkan digaji semua, sementara Jakarta tidak 
ada pengurusnya yang digaji, hanya petugas profesional yang mendapat gaji. Sebagai lembaga bentukan Pemerintah DKI Jakarta P2TP2Aadalah lembaga yang khusus melakukan pelayanan terutama terhadap perempuan dan anak korban kekerasan yang marak di DKI Jakarta. Berdasarkan data, sepanjang tahun 2014 P2TP2A Provinsi DKI Jakarta telah melayani sebanyak 1612 korban kekerasan yang menimpa perempuan dan anak. Angka ini meningkat sekitar $8 \%$ dibandingkan tahun lalu (Tahun 2013 jumlah korban yang ditangani P2TP2A sejumlah 1517 korban. Seperti diketahui hampir setiap hari ada pemberitaan tentang kasus kekerasan yang menimpa perempuan dan anak, yang dapat disimak melalui media massa (baik elektronik dan media cetak).

Pada tahun 2014 terlihat bahwa klien yang datang langsung mengalami peningkatan yang cukup siginifikan sekitar $65 \%$ daripada klien yang dirujuk oleh lembaga lain. Hal ini menunjukkan bahwa eksistensi P2TP2A sudah mulai dikenal masyarakat sebagai lembaga pelayanan yang menangani kekerasan terhadap perempuan anak. Dalam melaksanakan misinya P2TP2A DKI Jakarta bekerjasama dengan mitra dari instansi atau lembaga lain yang sudah mengakui keberadaan P2TP2A dan peran fungsinya sebagai lembaga pelayanan publik yang dibutuhkan mereka dalam menyelesaikan permasalahan yang menimpa perempuan dan anak. Kerjasama yang dilakukan adalah dengan membuat Nota Kesepahaman untuk lebih mengefektifkan peran dan tugas masingmasing, misalnya kerjasama dengan Polda Metro Jaya yang sudah dilakukan sejak tahun 2006, dalam penanganan kasus yang berskala besar. Selain itu berbagai Instansi atau Dinas yang berada di pemerintahan daerah DKI Jakarta, karena P2TP2A DKI Jakarta berkedudukan di Ibukota, kerjasama juga dilaksanakan dengan Kementerian Lembaga yang berada di Jakarta.

Dalam menangani kasus-kasus P2TP2ADKI Jakarta telah menyediakan tenaga konselor dan bantuan hukum dalam membantu perempuan dan anak korban kekerasan dalam proses hukum. Semua proses hukum tidak banyak menemui kendala karena intensifnya judicial networking yang terjalin sesuai amanat PSO dan peraturan perundang-undangan yang berlaku. Pelayanan kesehatan diberikan P2TP2A secara gratis dengan bekerjasama dengan 17 Rumah sakit dan 44 Puskesmas di DKI Jakarta, dengan jenis layanan Rawat jalan, Rawat Inap maupun pembuatan Visum Et Repertum.

Beberapa pengalaman para korban kekerasan patut dicatat bahwa: a) konsep pemberian bantuan didasari persepsi bahwa korban adalah orang lemah tak berdaya yang (hanya) membutuhkan belas kasihan sehingga 'bantuan' yang diberikan tidak memadai, parsial dan justru potensial menimbulkan kesengsaraan baru; b) Korban dianggap harus bertanggung jawab sendiri atas kemalangan yang menimpanya, sehingga mereka sering harus berjuang sendiri tanpa dukungan orang lain dan atau masyarakat; dan c) karena relasi gendernya, korban acapkali mengalami proses reviktimasi (menjadi korban untuk kesekian kalinya), misalnya eksploitasi kesengsaraannya, atau malah menerima stigma dan pengucilan oleh keluarga atau komunitasnya sendiri. ${ }^{6}$

\section{Jaringan Kerjasama Lintas Sektor Dalam Pemenuhan Hak Perempuan Korban Kekerasan}

Belum terbangunnya pemahaman yang sama antar para pemangku kepentingan, penegak hukum, pemerintah serta masyarakat bahwa persoalan kekerasan terhadap perempuan dalam perkawinan dan keluarga yang mewujud dalam bentuk kekerasan dalam rumah tangga adalah merupakan suatu bentuk pelanggaran terhadap martabat kemanusiaan. Masih terdapat pemahaman keliru yang memandang KDRT merupakan delik aduan, padahal tidak semua delik dalam Undang-Undang Penghapusan Kekerasan Dalam Rumah Tangga merupakan delik aduan.

Berjalannya layanan PPT masih bertumpu pada komitmen Badan Pemberdayaan Perempuan serta masih terbatas pada upaya perawatan medis dan hukum. Ini pun tidak berjalan dengan baik. Sementara hak perempuan korban atas pendidikan, pekerjaan, jaminan sosial, perumahan dan sebagainya tidak pernah diupayakan untuk memampukan atau memberdayakan korban dan keluarganya,

6 Komnas Perempuan, Layanan Terpadu - Pertautan Multi Disiplin dan Sinergi Kekuatan Masyarakat dan Negara (Cet.Kedua, Jakarta: Komnas Perempuan , 2005). 
sehingga dalam beberapa kasus justru korbanya mengalami berbagai bentuk kekerasan atau pelanggaran hak asasi yang baru.

Persoalan lain adalah aparat penegak hukum yang tidak mengetahui hak-hak korban atas kebenaran, keadilan dan pemulihan sebagai hak yang tidak dapat dipisahkan satu dengan lainnya. Hal itu terjadi karena secara umum aparat penegak hukum belum memiliki perspektif HAM dan gender maupun hak anak. Kalaupun ada jumlahnya tidak banyak dan tidak tersebar dengan baik diseluruh Indonesia, akibatnya tidak jarang ada upaya-upaya mendamaikan antara pelaku dan korban yang notabene suami istri.

Sebagian organisasi atau kelompok masyarakat lainnya, juga telah mengembangkan layanan bagi perempuan korban kekerasan. Layanan tersebut meliputi layanan medik di rumah sakit atau pusat kesehatan; layanan hukum melalui lembaga bantuan hukum maupun lembaga kepolisian; serta layanan psikologi berupa pendampingan atau konseling. Layanan juga dapat diarahkan untuk menguatkan sistim pendukung di lingkungan sosial korban. Respon lain yang juga sangat penting adalah pada aras kebijakan, baik dengan menggunakan sarana dan sistim hukum yang berlaku, maupun menyusun kebijakan yang dapat dipakai untuk melindungi, bahkan mengubah kearah yang lebih adil bagi perempuan korban kekerasan. Semua aksi ini selayaknya dapat dijalankan secara operasional pada semua sektor, baik yang didasari oleh konsensus sosial di tingkat masyarakat maupun yang didasari adanya suatu kebijakan nasional yang dicanangkan oleh pemerintah.

Pemerintah Provinsi Papua juga telah menunjuk Rumah Sakit Bhayangkara untuk menangani perempuan korban Kekerasan. Rumah Sakit ini memberikan layanan gratis dalam pemenuhan hak kesehatan. Permasalahan yang ada hanya pada koordinasi dengan instanasi terkait. Penanganan kesehatan yang dilakukan selama ini hanya berdasarkan pengaduan dari kekerasan yang dialami oleh korban. Oleh karenanya perlu ada koordinasi dengan instansi terkait agar kasus kekerasan terhadap perempuan bisa ditangani secara terpadu sampai proses penegakan hukum. Rekam medis tentang korban akan sangat berguna bagi proses penegakan hukum. Hal ini disebabkan ketidaktahuan korban dan kurangnya koordinasi antar lembaga pelayanan.

Lembaga lain yang menangani korban Kekerasan terhadap perempuan dan anak adalah Pusat Pelayanan Terpadi Perempuan dan Anak (P2TPA) yang dibentuk Provinsi Papua dibawah koordinasi Biro Pemberdayaan Perempuan dan Perlindungan Anak. Seperti yang diamanatkan Standar Pemayanan Minimal penanganan kekerasan terhadap perempuan dan anak menjadi tugas pokok utamanya. Namun P2TPA masih belum berfungsi secara optimal, hal ini dikarenakan kendala baik sumber daya manusia maupun situasi teknis seperti terjadinya pergantian Kepala Daerah yang berpengaruh besar terhadap kesinambungan kinerja P2TPA. Oleh karena itu pemenuhan hak perempuan dan anak korban Kekerasan menjadi sesuatu yang sulit untuk dipenuhi. Meskipun demikian berdasarkan data yang ada P2TPA Provinsi Papua cukup tinggi dalam menerima pengaduan. Oleh karenanya perlu SOP yang jelas yang dijalankan secara bertanggungjawab oleh petugas meski SDM memang dirasakan tidak memadai.

Selain P2TP2A Sulawesi Utara, Kepolisian Daerah Sulawesi Utara juga menjadi tempat tujuan pengaduan korban Kekerasan, namun pengaduan permasalahan yang terkaitkekerasan terhadap perempuan dan anak tidak langsung ke Unit Pelayanan Perempuan dan Anak (PPA). Pengaduan masuk ke Sentra Pelayanan Kepolisian Terpadu (SPKT) kemudian masuk Direktur dan disposisinya ke Bagian Pembinaan Operasi dan diteruskan ke Jatanras. Unit PPA perannya hanya untuk meminta keterangan, bukan penerimaan pengaduan langsung.

Pusat Pelayanan Terpadu selain di P2TP2A Sulawesi Utara, ada juga di Rumah Sakit Bhayangkara Manado. Pelayanannya termasuk pemulihan dan terapi dan perawatan yang cukup baik. Pemulihan dan pendampingan medis juga berjalan cukup baik, termasuk pengeluaran Visum et Repertum. Pelayanan ini dilaksanakan mulai dari pengaduan sampai perawatan dan rehabilitasi dengan gratis. Kasus yang ditangani dengan Pelayanan PPT Rumkit Bhayangkara cukup tinggi, tetapi pelayanan konseling tidak ada karena RS belum mempunyai Psikolog/ Psikiater. Kerjasama dan koordinasi terjadi dengan RS Malalayang apabila memerlukan 
pelayanan psikososial. Untuk penanganan proses hukum belum ada kerjasama dengan Polda maupun Polres, sehingga penanganan menjadi terhambat, sehingga perlu dibuat nota kesepahaman bersama.

Kerjasama penanganan perempuan dan anak korban kekerasan cukup baik justru dilakukan oleh PKK Provinsi Sulawesi Utara. PKK merupakan satu lembaga yang menangani perempuan dan anak korban Kekerasan, mulai dari pengaduan, kesehatan, pendampingan hukum dan layanan rumah aman. Layanan rumah aman akan dirujuk ke shelter yang ada di Sulawesi Utara. Selain lembaga diatas Sulawesi Utara ada lembaga Perlindungan Anak yang memberikan layanan psikososial.

Peran Polda Metro Jaya juga sangat besar dalam penyelesaian kasus Kekerasan. Penanganan pengaduan dan sampai pada proses bantuan dan penegakan hukum sebagai upaya mendorong untuk melakukan proses pengadilan yang adil bagi pelaku Kekerasan terhadap perempuan dan anak. Nota Kesepahaman kerjasama antara P2TP2A dengan berbagai lembaga layanan ditingkatkan agar hasil semakin optimal terutama upaya penghapusan kekerasan terhadap perempuan dan anak. Misal Nota Kesepahaman P2TP2A dan Direskrimum Polda Metro Jaya yang diperpanjang sehingga hal ini juga membuahkan langkah progresif karena hampir 90\% kasus kekerasan terhadap perempuan di DKI telah dilaporkan ke polisi dan $100 \%$ kasus kekerasan terhadap anak telah diproses sesuai hukum. Pendampingan dan bantuan hukum bagi korban juga terus ditingkatkan dalam mengupayakan rasa keadilan bagi korban. P2TP2A juga mengembangkan sistem rujukan yang meliputi advokasi, audensi, jaringan kemitraan, koordinasi, rujukan dalam menangnai kasus kekerasan terhadap perempuan dan anak. Pemerintah Daerah DKI Jakarta juga membentuk pos pengaduan yang berada di kelurahan sehingga kasus penanganan kasus akan lebih terintegrasi dan menjadi ujung tombak dalam menindaklanjuti kasus kekerasan terhadap perempuan yang terjadi di seluruh wilayah DKI Jakarta. Kondisi tersebut dapat dilihat dalam grafik di atas yang menunjukkan bahwa seluruh wilayah DKI Jakarta rawan terhadap bahaya kekerasan terhadap perempuan dan anak, karena hampir setiap polres pernah menangani kasus Kekerasan.
Tingginya kasus kekerasan terhadap perempuan dan anak yang terjadi di seluruh wilayah DKI Jakarta, mendorong P2TP2A untuk terus memperkuat jejaring kerja dengan melibatkan berbagai mitra kerja di tingkat wilayah, termasuk para kader PKK dan kelompok masyarakat lainnya, seperti misalnya kelompok kerja (POKJA) ataupun Kelompok Sadar (POKDAR) lingkungan. Untuk menjaga konsistensi pelaksanaannya sehingga memberi dampak pada masyarakat, P2TP2A Jakarta perlu meningkatkan koordinasi lintas bidang atau lintas sektor(K/L)denganunitpelayananterpadu(UPPA, RPTC, RPSA, RPSW, Puskesmas, Rumah sakit, Lembaga Bantuan Hukum, BNP2TKI, LSM, dll) serta sosialisasi dan advokasi kepada pihakpihak yang terkait agar melaksanakan kewajiban mereka sesuai dengan apa yang ditetapkan dalam peraturan perundang-undangan dengan mengedapankan prinsip-prinsip keadilan, non diskriminsi (tanpa membedakan status, ekonomi dan memperhatikan kebutuhan yang terbaik bagi korban.

Pelayanan kesehatan juga sudah sangat baik dilakukan Rumah Sakit Rujukan maupun Puskesmas yang berada di wilayah DKI Jakarta. Hanya beberapa kendala yang ada misalnya: a) terbatasnya Rumah Sakit Rujukan, dan banyaknya mutasi yang terjadi dengan tenaga terlatih; dan b) dalam penanganan korban trafiking kendalanya pada pembiayaan pelayanan kesehatan korban transit Jakarta di Rumah Sakit atau Puskesmas rujukan sulit dialokasikan. Dinas Kesehatan hanya mensyaratkan KTP dan TKP DKI Jakarta.

Menurut Ketua P2TP2A Provinsi DKI Jakarta (Wien Ritola) bahwa dalam penanganan Korban Kekerasan terhadap Perempuan dan Anak di Provinsi DKI Jakarta, terlebih dengan kondisi masyarakat Jakarta yang multidimensi dengan beragamnya corak kekerasan dalam rumah tangga khususnya yang dialami oleh perempuan dan guna meredam tingginya angka kasus perceraian di Jakarta, makadilakukan pendekatan kepada keluarga terdekat dari si korban seperti suami dengan proses pendampingan yang melibatkan psikolog, tokoh agama, lembaga bantuan hukum dan sukarelawan lainnya. Kalau sesudah adanya pendampingan, sikap pelaku berubah, maka proses pemulihan bagi korban akan sangat baik, tetapi bila belum berubah juga 
adalah hak korban untuk terus didampingi oleh petugas P2TP2A DKI Jakarta. ${ }^{7}$

Untuk rumah Aman P2TP2A DKI Jakarta bekerjasama dengan Dinas Sosial Provinsi DKI Jakarta dan Kementerian Sosial RI dengan sistem merujuk. Oleh karena itu koordinasi dan pentingnya membangun jaringan sangat diutamakan P2TP2A DKI Jakarta. Mengingat pentingnya keamanan dan keselamatan bagi klien dari pengalaman banyaknya yang ditangani P2TP2A membutuhkan rumah aman yang representatif, terlebih apabila butuh penanganan khusus seperti misalnya apabila yang menjadi korban adalah anak yang berkebutuhan khusus. P2TP2A DKI Jakarta akan mengusulkan kepada Pemda DKI Jakarta untuk membuat rumah aman sekaligus rumah untuk pemulihan yang bisa memenuhi harapan klien nyaman, aman dan representatif.

\section{PENUTUP}

\section{Kesimpulan}

Dalam perspekstif pemenuhan HAM, pembentukan Pusat Pelayanan Terpadu (PPT) merupakan langkah yang sangat progresif karena merupakan implementasi pemenuhan HAM bagi perempuan yang menjadi korban kekerasan dalam berbagai aspek, baik pelayanan pengaduan, pelayanan kesehatan, pelayanan rehabilitasi sosial, pelayanan bantuan hukum dan pemulangan serta reintegrasi sosial. Dalam tataran kebijakan, peraturan pembentukan PPT sudah diatur, namun implementasinya masih banyak mengalami kendala. Konsep Pusat Pelayanan Terpadu (PPT) di daerah masih sangat beragam, tetapi umumnya merupakan pelayanan berjejaring yang berbasis masyarakat. Salah satu PPT yang saat ini dioptimalkan oleh Kementerian Pemberdayaan Perempuan dan Perlindungan Anak di setiap provinsi, kabupaten dan kota adalah Pusat Pelayanan Terpadu Pemberdayaan Perempuan dan Anak (P2TP2A) yang bentuknya masih berbeda-beda, sehingga konsepnya perlu disampaikan dengan panduan dari Kementerian Pemberdayaan Perempuan

7 Wien Ritola, "Penanganan Korban Kekerasan terhadap Perempuan dan anak di provinsi DKI Jakarta" (Makalah disampaikan pada Workshop Pembentukan Jaringan Peran Serta Pemda di Jakarta, 2014). dan Perlindungan Anak dan Kementerian Lembaga terkait lainnya.

Fakta di lapangan menunjukkan bahwa keberadaan PPT, baik berupa P2TP2A maupun Women Crisis Center (WCC) yang dibentuk oleh LSM mampu menjawab kebutuhan terkait perempuan sebagai korban tetapi eksistensi lembaga tersebut sangat tergantung pada komitmen pemerintah daerah untuk memberikan fasilitas dan mendukung dalam bentuk regulasi daerah dan alokasi anggaran. Jaringan kerja yang terbentuk di setiap daerah juga menunjukkan relevansi yang sangat signifikan dalam optimalisasi PPT. Prinsip keterpaduan dalam praktik terkait erat dengan proses penegakan hukum, sehingga sinergi PPT dan kepolisian sebagai ujung tombak menjadi temuan kunci dalam permasalahan. Beberapa contoh dalam penelitian menunjukkan bahwa praktek di DKI Jakarta dan Sumatera Utara mempunyai komitmen kuat dalam melaksanakan pelayanan penanganan dengan baik dan terkoordinasi. Baik itu melalui regulasi, maupun penganggaran yang baik sesuai kebutuhan pelayanan maupun sumber daya manusia yang memadai.

Advokasi kepada pemerintah daerah dalam alokasi kebijakan dan anggaran yang ada di APBD untuk memberikan pelayanan prima dalam upaya pencegahan dan penanganan kasus kekerasan terhadap perempuan di PPT menjadi prioritas yang harus diupayakan oleh pemerintah pusat karena kekerasan perempuan terbukti merupakan isu strategis di semua daerah seluruh Indonesia.

\section{Saran}

Kementerian Pemberdayaan Perempuan dan Perlindungan Anak segera menetapkan pedoman pelaksanaan PPT yang sistematis dan mudah diaplikasikan daerah untuk memberikan pelayanan terhadap perempuan dan anak korban kekerasan karena keberadaan PPT di Indonesia adalah perwujudan dari komitmen Pemerintah Indonesia sesuaiperaturan perundang-undangan untuk memenuhi hak-hak korban.

Kementerian Hukum dan HAM berkoordinasi dengan Kementerian Lembaga terkait Perempuan dan Anak untuk mengusulkan kepada Kementerian Pendayagunaan Aparatur Negara dan Reformasi Birokrasi membentuk suatu badan yang melakukan pelayanan terpadu dalam 
penanganan kekerasan terhadap perempuan. Pembentukan badan khusus diharapkan dapat memberikan pelayanan secara optimal yang melibatkan kerja lintas disiplin dan lintas sektoral melalui payung hukum yang kuat.

Kementerian Hukum dan HAM mendorong Kementerian Dalam Negeri untuk membuat peraturan atau surat edaran kepada Pemerintah Daerah yang berada di Indonesia untuk memasukkan isu kekerasan perempuan sebagai isu prioritas sehingga dapat mengalokasikan anggaran dan kebijakan untuk melindungi perempuan dari bahaya kekerasan.

Kementerian Hukum dan HAM mendorong aparat penegak hukum, yakni Kepolisian RI, Kejaksaan Agung dan Mahkamah Agung perlu melakukan koordinasi dalam mendorong terbentuknya kesepahaman dalam penanganan kasus kekerasan terhadap perempuan terutama terkait mekanisme sistem pembuktian dalam kasus kekerasan yang biasanya minim alat bukti.

\section{DAFTAR PUSTAKA}

\section{Buku}

Irianto, Sulistyowati. 2006. Perempuan \& Hukum: Menuju Hukum yang Berperspektif Kesetaraan dan Keadilan. Jakarta: Yayasan Obor Indonesia.

Komnas Perempuan. 2005. Layanan Terpadu - Pertautan Multi Disiplin dan Sinergi Kekuatan Masyarakat dan Negara. Jakarta: Komnas Perempuan Cet. Kedua.

Komnas Perempuan. 2013. Referensi bagi Hukum Pengadilan Agama tentang Kekerasan dalam Rumah Tangga. Jakarta: UNFPA.

Komnas Perempuan. 2015. Catatan Tahunan Komnas Perempuan Tahun 2015. Jakarta: Komnas Perempuan.

Sumanto. 1995. Metodologi Penelitian Sosial dan Pendidikan. Yogyakarta.

\section{Peraturan dan Undang-Undang:}

Republik Indonesia. Undang-Undang Nomor 21 Tahun 2007 tentang Pemberantasan Tindak Pidana Perdagangan Orang. Jakarta.
Undang-Undang Nomor 23 Tahun 2004 tentang Penghapusan Kekerasan Dalam Rumah Tangga.

Peraturan Menteri Pemberdayaan Perempuan dan Perlindungan Anak Republik Indonesia Nomor1 Tahun 2015 tentang Rencana Strategis Kementerian Pemberdayaan Perempuan dan Perlindungan Anak Tahun 2015-2019.

Peraturan Menteri Negara Pemberdayaan Perempuan dan Perlindungan Anak Republik Indonesia Nomor 01 Tahun 2010 tentang Standar Pelayanan Minimal (SPM) Bidang Layanan Terpadu Bagi Perempuan dan Anak Korban Kekerasan.

Peraturan Pemerintah Nomor 9 Tahun 2008 tentang, Tata Cara dan Mekanisme Pelayanan Terpadu bagi Saksi dan/atau Korban Tindak Pidana Perdagangan Orang.

\section{Presentasi Makalah}

Ritola, Wien. Ketua P2TP2A Provinsi DKI Jakarta dalam Workshop Pembentukan Jaringan Peran Serta Pemda dalam Penanganan Korban Kekerasan terhadap Perempuan dan anak di provinsi DKI Jakarta. Jakarta. 


